\title{
INSIDENSI KHOLANGITIS KRONIK SEBAGAI MANIFESTASI EKSTRAINTESTINAL PENDERITA IBD DI RSPAD GATOT SOEBROTO JAKARTA PUSAT
}

\author{
H. Syafruddin ARL ${ }^{1}$, Ruswhandi Martamala ${ }^{2}$ \\ ${ }^{1,2}$ Departemen Penyakit Dalam RSPAD Gatot Soebroto Jakarta Pusat \\ Email: syafrudin.arl@gmail.com
}

\begin{abstract}
ABSTRAK
IBD (Inflammatory Bowel Disease) adalah penyakit radang kronik usus dimana manifestasi klinis intraintestinal dominan berupa diare kronik dan nyeri perut. Adapun manifestasi ekstraintestinal dominan berupa Kholitis kronik dalam bentuk Perikholangitis atau Primary Sclerosing Cholangitis (PSC) yang muncul setelah beberapa tahun kemudian dari timbulnya kasus IBD dengan incidence rate $5 \%$. Ingin mengetahui angka insidensi (incidence rate) IBD serta PSC pada semua pasien yang dikolonoskopi dari 1 Maret 2016 - 28 Februari 2017 di Pusat Endoskopi RSPAD Gatot Soebroto. Subyek penelitian adalah semua pasien yang dikolonoskopi selama satu tahun. Data Kholitis kronik (Khk) didasarkan atas temuan AST (SGOT) dan bilirubin total serum yang meningkat serta albumin serum yang menurun, dipilah menjadi kelompok Khk-IBD atau PSC, Khk-non-IBD, Non-Khk-IBD, Non-Khk-non-IBD. Insidensi PSC dan korelasi antara PSC dengan IBD diuji dengan uji mutlak Fisher. Bahan penelitian diambil secara retrospektif deskriptif, Data PSC dan IBD pasien yang mengalami kolonoskopi. Angka Insidensi IBD dan PSC 18,6\%, 5,4\%; ada Korelasi PSC dengan IBD sebagai manifestasi ekstra intestinal ( $\mathrm{p}=0,000$ ); Dari data demografi IBD (30 orang), laki-laki 62,4\% (18 orang), rerata umur 50,6 tahun, angka kejadian terbanyak pada usia 40 - 59 tahun.
\end{abstract}

Kata Kunci : Angka Insidensi; Inflammatory Bowel Disease; Manifestasi Ekstraintestinal Demografi; Primary Sclerosing Cholangitis

\begin{abstract}
IBD (Inflammatory Bowel Disease) as a disease of inflammation of chronic intestinal. The extraintestinal manifestation is predominantly in the form Pericholangitis, chronic cholitis or primary sclerosing cholangitis (PSC), which usually appear after a few years later from the pop-up cases of IBD with the incidence rate of 5\%. Want to know the incidence rate of IBD and PSC in patients were undergoing colonoscopy at RSPAD GS since of March 1, 2016 until February 28, 2017. All patients were undergoing colonoscopy for one year included as a subject of research. Subjects sorted and selected on the findings of the colonoscopy as IBD and non-IBD. Data Cholitis chronic (KHK) is based on the findings of aspartate aminotransferase (AST) and total bilirubin elevated serum and serum albumin divided into groups of KHK-IBD or PSC, KHK-non-IBD, Non-KHK-IBD and NonKHK-non-IBD. Correlation between the PSC and the PSC with IBD were tested statistically by Fisher, materials taken retrospective descriptive. Data PSC and IBD patients as follows: The incidence rate of IBD and PSC are 18.6\% and 5.4\%; Correlation PSC with extraintestinal manifestation of IBD acceptable expectation $(\mathrm{p}=0.000)$; demographic data of IBD (30 patients) with male $62.4 \%(18$ people), mean age was 50.6 years and incidence between $40-59$ years old.
\end{abstract}

Keywords : Demographic Data; Extraintestinal Manifestations; Incidence Rates, Inflammatory Bowel Disease, Primary Sclerosing Cholangitis

\section{PENDAHULUAN}

Angka kejadian dan manifestasi klinis Inflammatory bowel disease (IBD) bervariasi tergantung pada area geografis dan asal populasi. ${ }^{1}$ Angka kejadian IBD di negara-negara barat cenderung plateau, akan tetapi di wilayah Asia justru meningkat. $^{2}$ Pada beberapa penelitian 
menunjukkan bahwa manifestasi klinis penderita IBD di negara Asia lebih ringan dibandingkan negara-negara Barat. Salah satunya adalah penelitian oleh Li Jiang, dkk (2006), yang menunjukkan bahwa dari 452 pasien yang diperiksa, keluhan yang paling banyak adalah diare dan nyeri abdomen. ${ }^{3}$ Laporan studi tentang IBD, jarang mengungkapkan temuan manifestasi klinis ekstraintestinal IBD itu sendiri.

Kholangitis kronik sebagai manifestasi gangguan abnormalitas hepatobilier, sering dihubungkan serta merupakan salah satu manifestasi ekstraintestinal IBD, dikenal sebagai Primary sclerosing cholangitis atau Pericholangitis. ${ }^{4}$ Tidak ada perasat yang spesifik untuk gejala yang sering menyertai manifestasi ini, namun pada umumnya adalah nyeri abdomen, demam, fatique, pruritus dan kholestatik berupa peningkatan bilirubin direk dan aspartate transaminase (AST/SGOT); diikuti oleh tanda-tanda hepatosplenomegali dan hiperpigmentasi. ${ }^{5}$

Tujuan penelitian untuk mengungkap insidensi dan korelasi antara IBD dan Kholangitis kronik dengan pendekatan hasil kolonoskopi sebagai dasar penegakan diagnosis IBD serta dengan kriteria klinis diagnosis Kholangitis kronik dari semua pasien yang mengalami tindakan kolonoskopi gastrointestinal di Ruang Pusat Endoskopi RSPAD Gatot Soebroto Puskesad.

\section{TINJAUAN PUSTAKA}

Inflammatory bowel disease (IBD) merupakan kondisi keradangan kronik saluran cerna yang berkaitan dengan proses imun, terdiri dari Kolitis ulseratif (KU / Ulcerative Colitis - UC) dan Penyakit Crohn (PC / Crohn's Disease - CD) yang merupakan dua bagian utama IBD, disamping Indetermined Colitis (IC) untuk jenis colitis terduga IBD yang sulit di identifikasi antara kedua sebelumnya. ${ }^{1}$ Penanda KU adalah inflamasi/peradangan mukosa yang luas dan dangkal serta terbatas hanya pada kolon. Luasnya peradangan ini dapat dibagi menjadi bagian distal dan peradangan yang lebih luas (ekstensif). Yang dimaksud dengan bagian distal adalah kolitis yang meliputi rektum (proctitis) atau rektum dan kolon sigmoid (proctosigmoiditis). ${ }^{2-5}$ Sedangkan peradangan yang agak luas (pre-ekstensif) adalah kolitis sisi kiri (hingga ke splenic flexure); peradangan yang lebih luas disebut kolitis ekstensif (hingga ke hepatic flexure) dan pankolitis (meliputi seluruh kolon). ${ }^{6}$ Penyakit Crohn (PC) ditandai dengan bercak inflamasi transmural yang dapat mengenai bagian manapun dari saluran cerna. Dapat dibagi berdasarkan lokasi, yaitu bagian akhir usus halus (ileocolitis), kolon, serta saluran cerna atas atau berdasarkan pola penyakit (inflamasi, fistula, atau striktura).

Secara umum, IBD dihubungkan dengan gangguan kinerja imunologik pada jaringan saluran cerna yang mengalami radang (immunologic mechanism of colon tissue injury); hal ini terlihat dari aktivasi sel-T di lamina propria, walaupun triggernya belum diketahui pasti. Teori popular respons imun berupa aktivasi sel limfoid $\mathrm{T}$ helper ini berbeda antara KU dan PC. Pada PC yang berperan adalah $\mathrm{T}$ helper 1 (Th1), sedangkan pada KU adalah sel limfoid T helper 2 (Th-2). ${ }^{7}$ Selain itu, pada KU terlihat distribusi perinuclear antineutrophil cytoplasmic antibodies (pANCA) yang meningkat sampai $60 \%-70 \%$ kasus, sebaliknya hanya kadang-kadang ditemukan pada PC, dimana p-ANCA tidak terlibat dalam pathogenesis $\mathrm{PC}$, melainkan dikaitkan dengan HLA- DR2 allele. Namun jika pada KU p-ANCA tidak terlihat (KU dengan p-ANCA negative), maka adanya $\mathrm{KU}$ dapat ditunjukkan dengan HLA-DR4 yang positive. Hal ini dapat mendukung untuk pembedaan antara PC dengan KU. ${ }^{4}$

Gejala yang paling banyak dialami pada KU adalah diare, nyeri perut hebat, pendarahan rektum, tenesmus dan keluarnya lendir peranum. Beratnya gejala berhubungan dengan luasnya penyakit. Meskipun KU dapat muncul secara akut, 
gejala biasanya telah timbul selama beberapa minggu hingga bulan sebelumnya. Kadangkala, diare dan perdarahan sangat jarang dan ringan sehingga pasien tidak mencari pertolongan medis. Pasien dengan luas peradangan yang terbatas seperti proktitis, biasanya mengalami gejala yang ringan namun sering berulang, sedangkan pasien dengan pankolitis lebih sering mengalami gejala yang berat, terutama rasa nyeri pada perut yang membawa pasien sering memerlukan perawatan di rumah sakit. Pada proktitis, biasanya terdapat darah segar atau lendir yang disertai darah, bisa bercampur dengan feses atau melapisi permukaan feses normal atau padat. Muncul juga keluhan seperti tenesmus, atau adanya urgency dengan keinginan pengeluaran feses yang tidak lampias, sedangkan keluhan nyeri perut jarang terjadi. Apabila kelainan terjadi jauh di atas rektum, darah biasanya bercampur dengan feses atau diare bercampur darah yang sangat banyak. Motilitas kolon dipengaruhi oleh inflamasi yaitu isi usus akan sangat cepat melalui bagian usus yang meradang. Pada penyakit yang berat, pasien mengeluarkan feses cair yang bercampur darah, dan nanah. Diare seringkali muncul malam hari dan atau setelah makan. Meskipun nyeri hebat bukan merupakan gejala yang menonjol, beberapa pasien dengan penyakit yang aktif dapat mengalami rasa tidak nyaman pada perut yang tidak terlalu jelas atau kram ringan pada perut bagian tengah. Kram dan nyeri perut hebat dapat terjadi pada penyakit yang berat. Beberapa gejala lain pada penyakit yang sedang hingga berat meliputi anoreksia, mual, muntah, demam dan turun berat badan. ${ }^{2}$

Diagnosis PC tidak mudah ditegakkan, oleh karena manifestasi klinis yang sangat bervariasi, penampakan klinis yang mirip dengan penyakit peradangan saluran cerna yang lain, atau karena adanya presentasi klinis lain (ekstraintestinal) tanpa gejala saluran cerna. Gejala khas seperti diare dan nyeri perut kronik dan nokturnal, penurunan berat badan, demam, atau pendarahan rektum menggambarkan proses peradangan yang terjadi. Tandatanda klinis antara lain pucat, kaheksia, dan massa abdominal atau nyeri perut, atau fisura perianal, fistula, atau abses. Penyakit Crohn (PC) yang terbatas pada kolon memberikan gejala seperti pendarahan rektum, komplikasi perianal dan komplikasi ekstraintestinal, meliputi kulit, mata, sistim hepatobilier atau persendian dan sulit dibedakan dengan komplikasi pada kolitis ulseratif.

Manifestasi ekstraintestinal antara lain melibatkan mata (scleritis, uveitis), kulit (eritema nodosum), atau persendian (spondiloartritis, artritis perifer) dan hiperkoagulabilitas, serta gangguan hepato-bilier (primary sclerosing cholangitis), ${ }^{4,5}$ seperti yang dilaporkan di $\mathrm{Iran}^{8}$ dan ditekankan dalam Klasifikasi Montreal. ${ }^{9}$

Pemeriksaan baku pada IBD adalah pemeriksaan endoskopi berupa kolonoskopi, sigmoidoskopi fleksibel dan untuk membedakan antara PC dan KU, perlu dilakukan ileokolonoskopi dengan biopsi. Disamping itu mungkin diperlukan pemeriksaan Barium enema maupun $X$-ray abdomen standar. ${ }^{10,11}$ Endoskopi sangat bermanfaat tidak hanya untuk memeriksa pengisian lesi pada barium enema, mengetahui lokasi peradangan yang akan menentukan prognosis dan terapi, akan tetapi juga sangat berperan penting untuk tindakan biopsi dan menentukan keputusan untuk dilakukan tindakan operasi. Pada salah satu studi prospektif, dikatakan bahwa ileokolonoskopi memiliki keakuratan $80-90 \%$ dalam membedakan KU dan PC. ${ }^{10}$ Disamping itu sesuai keperluan dapat dilakukan tes dan tindakan diagnostik berupa tes darah, pemeriksaan sampel feses. Sedangkan penanda laboratorium seperti genetic marker dan immunologic marker tidak begitu berpengaruh, karena tidak menentukan ada-tidaknya IBD. ${ }^{11}$

Secara klinis, IBD diklasifikasikan dalam beberapa klasifikasi yang akan menentukan prognosis dan terapi yang 
akan diberikan. ${ }^{9}$ Pada PC, digunakan klasifikasi Montreal yang merupakan revisi dari klasifikasi sebelumnya yaitu klasifikasi Vienna, lihat tabel 1. Pada klasifikasi ini, terdapat tiga komponen yang dipertimbangkan, yaitu usia (Age) saat munculnya penyakit (A), lokasi (location) terjadinya inflamasi (L), dan bentuk-sifat (behaviour) kelainan yang terjadi (B).

Tabel 1. Klasifikasi Montreal dan Vienna untuk penyakit Crohn (PC) ${ }^{9}$

\begin{tabular}{|c|c|c|}
\hline & Vienna & Montreal \\
\hline Age at diagnosis & $\begin{array}{l}\text { A1 below } 40 y \\
\text { A2 above } 40 y\end{array}$ & $\begin{array}{l}\text { A1 below } 16 y \\
\text { A2 between } 17 \text { and } 40 y \\
A 3 \text { above } 40 y\end{array}$ \\
\hline Location & $\begin{array}{l}\text { L1 ileal } \\
12 \text { colonic } \\
13 \text { ileocolonic } \\
\text { L4 upper }\end{array}$ & $\begin{array}{l}\text { L1 ilect } \\
\text { L2 colonic } \\
\text { L3 ileocolonic } \\
\text { L4 isolated upper disease* }\end{array}$ \\
\hline Behaviour & $\begin{array}{l}\text { B1 non-stricturing, non-penetrating } \\
\text { B2 stricturing } \\
\text { B3 penetrating }\end{array}$ & $\begin{array}{l}\text { B1 non-stricturing, non-penetrating } \\
\text { B2 stricturing } \\
\text { B3 penetrating } \\
\text { P perianal disease modifiert }\end{array}$ \\
\hline
\end{tabular}

- $\mathrm{LA}$ is a modifier that can be added to $\mathrm{L} 1-\mathrm{L} 3$ when concomitant upper gastrointestinal disease is present.

$t^{\prime \prime} \mathrm{P}$ " is added to $\mathrm{B} 1-\mathrm{B} 3$ when concomitant perianal disecase is present.

Untuk KU, klasifikasi klinis dibagi berdasarkan luas (Extension-E) dan derajat berat (Severity-S)-nya kelainan. Berdasarkan luasnya kelainan (E), KU terbagi dalam tiga kategori Proctitis (E1), KU distal (E2) dan Pancolitis (E3), lihat
Tabel 2 Sedangkan berdasarkan severitas (S), aktifitas kelainan KU ini terbagi dalam empat kategori, yakni KU asimptomatik (SO), KU aktif-ringan (S1), KU aktif-sedang dan KU aktif-berat (Tabel $3)$.

Tabel 2. Klasifikasi Montreal berdasarkan luasnya kelainan kolitis ulseratif ${ }^{9}$

\begin{tabular}{|c|c|c|}
\hline Extent & & Anatomy \\
\hline El & Ulcerafive proctitis & $\begin{array}{l}\text { Involvement limited to the rectum (that is, proximal extent of } \\
\text { inflammation is distal to the rectosigmoid junction) }\end{array}$ \\
\hline E2 & Left sided UC (distal UC) & $\begin{array}{l}\text { Involvement limited to a proportion of the colorectum distal to the } \\
\text { splenic flexure }\end{array}$ \\
\hline E3 & Extensive UC (pancolitis) & Involvement extends proximal to the splenic flexure \\
\hline
\end{tabular}

Kelompok Studi IBD Indonesia (KSIBDI) sebagai badan otonom dalam kepengurusan Pengurus Besar Perkumpulan Gastroenterologi Indonesia (PB PGI) telah menyusun suatu Konsensus Nasional Penatalaksanaan IBD di
Indonesia yang disosialisasikan pada tahun 2011 (disebut KNP IBD 2011) untuk menegakkan diagnosis IBD per endoskopi secara praktis dengan merumuskan acuan temuan hasil kolonoskopi (Tabel 4). ${ }^{12}$

Tabel 3. Klasifikasi Montreal berdasarkan beratnya penyakit kolitis ulseratif ${ }^{9}$

\begin{tabular}{|c|c|c|}
\hline Severity & & Definition \\
\hline SO & Clinical remission & Asymptomatic \\
\hline SI & Mild UC & $\begin{array}{l}\text { Passage of four or fewer stools/day (with or without blood), absence of any } \\
\text { systemic illness, and normal inflammatory markers (ESR) }\end{array}$ \\
\hline $\begin{array}{l}\text { S2 } \\
\text { S3 }\end{array}$ & $\begin{array}{l}\text { Moderate UC } \\
\text { Severe UC }\end{array}$ & $\begin{array}{l}\text { Passage of more than four stools per day but with minimal signs of systemic toxicity } \\
\text { Passage of at least six bloody stools daily, pulse rate of at least } 90 \text { beats per minute, } \\
\text { temperature of at least } 37.5^{\circ} \mathrm{C} \text {, hoemoglobin of less than } 10.5 \mathrm{~g} / 100 \mathrm{ml} \text {, and ESR of } \\
\text { at least } 30 \mathrm{~mm} / \mathrm{h}\end{array}$ \\
\hline
\end{tabular}


Tabel 4. Acuan Temuan Hasil Kolonoskopi Untuk Penegakan Diagnosis IBD

\begin{tabular}{lcccc}
$\begin{array}{c}\text { TEMUAN } \\
\text { KOLONOSKOPI }\end{array}$ & $\begin{array}{c}\text { Kerapuhan } \\
\text { mukosa }\end{array}$ & $\begin{array}{c}\text { Aphthous } \\
\text { dan Ulkus } \\
\text { linear }\end{array}$ & $\begin{array}{c}\text { Cobble stone } \\
\text { dan Skip } \\
\text { area }\end{array}$ & Pseudo olip \\
\hline Kolitis Ulseratif (KU) & +++ & 0 & 0 & ++ \\
\hline Penyakit Crohn (PC) & + & ++ & $++/++$ & + \\
\hline Penyakit lain (Non-IBD) & $0 /+/++$ & +++ & $0 /+$ & 0 \\
\hline Keterangan: & $\begin{array}{l}\text { = Tidak ada; } \\
++\end{array}$ & $\begin{array}{l}+ \\
\text { = Sering }\end{array}$ & +++ Kadang kadang/hampir sering; \\
\end{tabular}

Gambaran epidemiologi kasus IBD akhir-akhir ini cenderung semakin meningkat di negara-negara Asia. Salah satu studi di negara Cina yang melibatkan 452 pasien IBD menunjukkan bahwa rerata usia pasien dengan $\mathrm{KU}$ adalah $42+14,5$ tahun, sedangkan pasien dengan PC adalah $32,6+12,5$ tahun. $^{3}$ Studi di Iran, menunjukkan hasil yang serupa yaitu usia rerata pasien KU adalah 37,2+13,7 tahun, sedangkan pada PC adalah 33,8+12,9 tahun. ${ }^{8}$ Perbandingan antara laki-laki dan perempuan pada PC dan KU secara berurutan adalah 0,9 dan 0,7.5 Angka ini lebih rendah dibandingkan dengan studi yang dilakukan di Cina, yaitu 2,32 dan $1,53 .^{3}$ Namun, data yang ada tidak menunjukkan manifestasi klinis ekstraintestinal IBD.

Di Indonesia, angka insidensi dan prevalensi berbeda-beda antar tiap-tiap daerah dan umumnya berbasis rumah sakit (Hospital base data). Dilaporkan dalam buku Konsensus Nasional Penatalaksanaan IBD di Indonesia tahun 2011 (KNP IBD 2011) bahwa, Ari FS, dkk (2008) menunjukkan karakteristik KU dan PC di RSCM Jakarta selama periode 2001 - 2006 dengan prevalensi IBD 8,3\%; di RSPAD Gatot Soebroto Ditkesad Jakarta, Lelosutan, dkk (2008) melaporkan pula dari 532 kasus yang mengalami kolonoskopi selama 5 tahun (2002-2006), rerata prevalensi IBD adalah $10,15 \% .^{12}$ Namun dari data tersebut juga tidak digambarkan bagaimana manifestasi klinis ekstraintestinal IBD.

Presentasi Kholangitis sklerosing primer (PSC - primary sclerosing cholangitis), berkaitan dengan kondisi Kolitis kronik pada hampir $70 \%$ kasus serta sering dikaitkan dengan abnormalitas proses imun pada IBD dan merupakan manifestasi ekstraintestinal IBD.

Disamping itu, agen toksin dan virus yang terserap dari inflamed colon, termasuk bakteri peptides seperti $\mathrm{N}$ formylated chemotactic peptides dan endotoksin memacu keluarnya sitokinsitokin inflamasi sehingga menyebabkan bile duct injury. ${ }^{4,5,13}$ Peran kinerja faktor imun Haplotypes HLA-B2 dan HLA-DR3 sering muncul dan meningkat pada PSC.

Estimasi klinis menyebutkan bahwa pada 5\% kasus KU akan ditemukan PSC beberapa tahun setelah munculan IBD. ${ }^{5}$ Kriteria penegakan diagnosis PSC terutama didasarkan atas pemeriksaan abnormalitas sampel darah (direct hyperbilirubinemia, hypoalbuminemia, hyperaspartate transaminasemia) dan radiologic imaging saluran empedu. ${ }^{1}$

Penelitian ini bertujuan untuk mengetahui insidensi Kholangitis kronik (PSC) dan korelasinya sebagai manifestasi ekstraintestinal pada penderita IBD (inflammatory bowel disease) selama satu tahun di Rumah Sakit Pusat Angkatan Darat Gatot Soebroto Puskesad.

Hasil penelitian ini diharapkan dapat meningkatkan kemampuan penegakan diagnosis klinis pada pasien IBD sebelum dilakukan pemeriksaan kolonoskopi. Selain itu, penelitian ini diharapkan dapat mengetahui insidensi manifestasi ekstraintestinal kholangitis kronik (PSC) pada IBD di RSPAD Gatot Soebroto Puskesad. 
METODE PENELITIAN

\section{Metodologi dan Populasi Sampel.}

Penelitian ini merupakan penelitian retrospektif deskriptif, dengan populasi terjangkau berdasarkan semua pasien yang mengalami kolonoskopi di ruang Pusat Endoskopi Rumah Sakit Pusat Angkatan Darat (RSPAD) Gatot Soebroto Puskesad selama bulan 1 Maret 2016 sampai dengan 28 Februari 2017; dimasukkan sebagai subyek penelitian dengan kriteria inklusi : (1) Pemeriksaan kolonoskopi dilakukan oleh operator ahli/konsultan gastroenterologi; (2) Diagnosis IBD ditegakkan berdasarkan hasil pemeriksaan kolonoskopi sesuai Klasifikasi Montreal dan KNP IBD 2011; dan (3) Diagnosis PSC ditegakkan berdasarkan kriteria adanya data awal pre-endoskopi berupa hiperbilirubinemia direk, hipoalbuminemia dan AST (aspartate transaminase) yang meningkat pada subyek yang mengalami kolonoskopi dalam periode waktu satu tahun tersebut.

Pasien dieksklusi bila tidak ditemukan data dasar yang diambil dari rekam medis.

Rancangan cara kerja pada penelitian, sebagai berikut :

1. Data demografi subyek diambil berdasarkan data registrasi pasien yang masuk sebagai subyek penelitian.

2. Untuk data demografi dan karakteristik IBD, subyek dengan hasil kolonoskopi yang menunjang diagnosis IBD dikumpulkan datanya meliputi : (1) usia, (2) jenis-kelamin, (3) rumusan masalah klinis (dasar indikasi) sebelum pemeriksaan kolonoskopi, (4)

kesimpulan hasil temuan

pemeriksaan kolonoskopi dan (5) hasil pemeriksaan patologi anatomi.

3. Untuk melihat korelasi PSC dengan IBD, semua subyek yang mengalami kolonoskopi dinilai kriteria diagnosis PSC-nya dan dipilah dalam tabel $2 \times 2$ berdasarkan kelompok IBD dan Non-IBD. Untuk uji statistik, dipakai perhitungan korelasi uji mutlak Fisher untuk tabel $2 \times 2$ karena mempunyai nilai ekspektasi dengan distribusi ekstrim ( $\mathrm{p}<$ 0.05). ${ }^{14,15,16}$

\section{Tempat dan Waktu Penelitian.}

Penelitian ini dilakukan di Departemen Penyakit Dalam Rumah Sakit Pusat Angkatan Darat (RSPAD) Gatot Soebroto Puskesad dengan persiapan sudah dimulai pada bulan Februari 2016. Pengambilan data sampel hasil kolonoskopi dimulai pada 1 Maret 2016 dan berakhir pada 28 Februari 2017

\section{HASIL PENELITIAN \\ Karakteristik demografik.}

Jumlah pasien dari register ruang endoskopi gastrointestinal Departemen Penyakit Dalam RSPAD Gatot Soebroto yang mengalami tindakan kolonoskopi dari 28 Februari 2012 sampai dengan 1 Maret 2016 adalah 161 pasien, dimasukkan sebagai subyek $(\mathrm{n}=161)$. Selanjutnya dipilah seperti pada Gambar 1 dibawah ini 


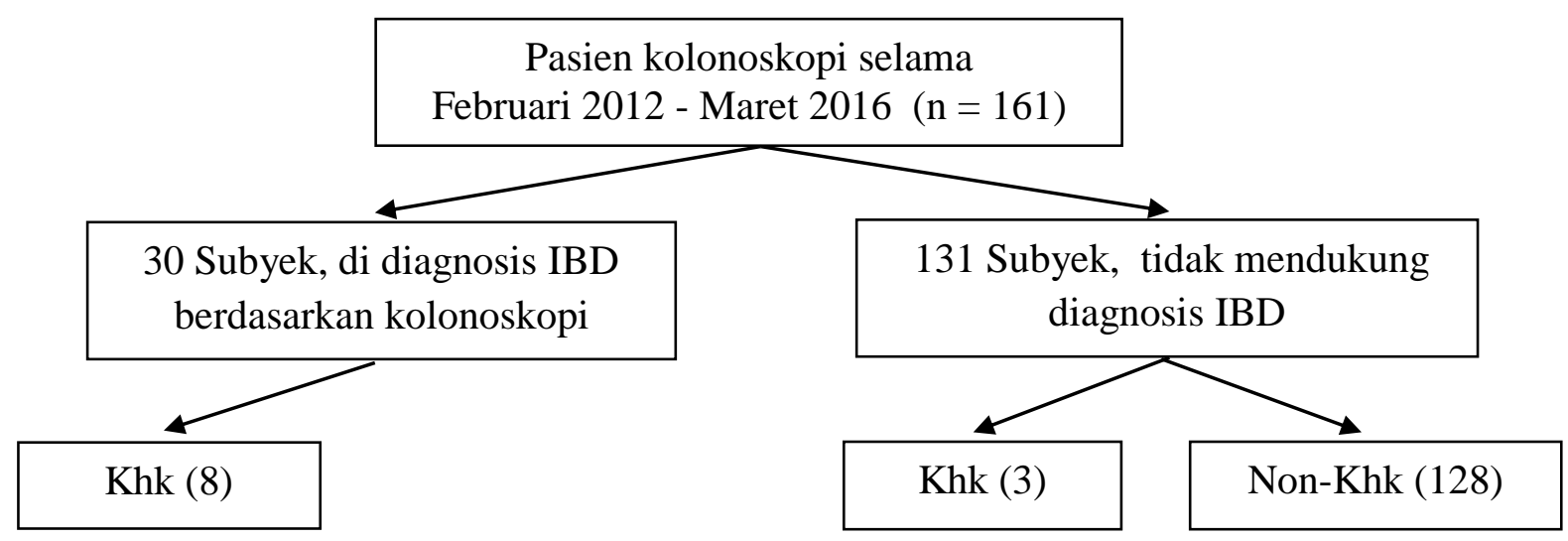

Keterangan : $\mathrm{IBD}=$ Inflammatory Bowel Disease, $\mathrm{Khk}=$ Kholangitis kronik; Non-Khk = Bukan Kholitis kronik, $\mathrm{n}=$ Subyek terjangkau.

Gambar 1. Pemilahan subyek penelitian

Seluruh subyek penelitian adalah 161 orang, 30 subyek merupakan penderita IBD dengan dasar diagnosis per kolonoskopi. Berarti insidensi IBD terhitung sebanyak $18,6 \%$.

Dari jumlah 30 subyek IBD tampak karakteristik demografi sebagai berikut :

1. $52,8 \%$ di diagnosis sebagai Penyakit Crohn (PC) dan 47,2\% di diagnosis sebagai Kolitis Ulseratif (KU).

2. Puncak kejadian IBD baik pada PC maupun KU adalah pada usia 40 hingga 59 tahun, dengan rerata umur adalah 50,6 tahun (SD: 12,8 th), dan umur terendah adalah 29 tahun dan tertinggi 71 tahun.

3. Perbandingan kejadian KU pada lakilaki dan perempuan seimbang 1:1, sedangkan pada PC angka kejadian pada laki-laki lebih banyak yaitu 2,2:1.

Tabel 5. Karakteristik demografi IBD dari subyek

\begin{tabular}{lcc}
\hline $\begin{array}{c}\text { Karakteristik } \\
\text { Demografis }\end{array}$ & $\begin{array}{c}\text { Kolitis } \\
\text { Ulseratif } \\
\mathbf{4 7 , 2 \%}(\mathbf{1 4})\end{array}$ & $\begin{array}{c}\text { Penyakit } \\
\text { Crohn } \\
\mathbf{5 2 , 8 \% ( 1 6 )}\end{array}$ \\
\hline Usia & & \\
$<20$ tahun & $0 \%$ & $0 \%$ \\
$20-39$ tahun & $6,6 \%(2)$ & $17,5 \%(5)$ \\
$40-59$ tahun & $29,7 \%(9)$ & $19,8 \%(8)$ \\
$>60$ tahun & $9,9 \%(3)$ & $9,9 \%(3)$ \\
Jenis Kelamin & & \\
Laki-laki & $24,1 \%(7)$ & $38,3 \%(11)$ \\
Perempuan & $24,1 \%(7)$ & $17,5 \%(5)$ \\
\hline
\end{tabular}

\section{Karakteristik Klinis.}

Masalah klinis sebagai indikasi sebelum dilakukan - pemeriksaan kolonoskopi subyek IBD (30) :

1. Pada tipe-KU yang paling sering adalah nyeri perut $(17,5 \%)$, diare kronik (13,2\%), dan hematoschezia $(6,6 \%)$.

2. Pada tipe-PC adalah diare kronik $(29,7 \%)$, nyeri perut $(9,9 \%)$ dan hematoschezia $(9,9 \%)$ (Tabel 6).

Tabel 6. Karakteristik klinis

\begin{tabular}{lcc}
\multicolumn{1}{c}{$\quad$ MASALAH } & KU $(\mathbf{n}=$ & PC $(\mathbf{n}=$ \\
Kiare kronik & $\mathbf{1 4})$ & $\mathbf{1 6})$ \\
Hematemesis & $13,2 \%(4)$ & $29,7 \%(9)$ \\
melena & $3,3 \%(1)$ & -- \\
Hematokhezia & $6,6 \%(2)$ & $9,9 \%(3)$ \\
Hemorrhoid & $3,3 \%(1)$ & -- \\
Nyeri perut & $17,5 \%(5)$ & $9,9 \%(3)$ \\
Fissura ani & -- & $3,3 \%(1)$ \\
Massa & $3,3 \%(1)$ & -- \\
rektosigmoid & & \\
\hline Total persentase & & \\
\hline
\end{tabular}

Korelasi Kholangitis kronik pada IBD.

Untuk menilai korelasi Kholangitis kronik (Khk) dengan IBD pada subyek, dilakukan penghitungan dan uji mutlak Fisher sesuai tabel $2 \times 2$ contingency, seperti pada Tabel 7. 
Tabel 7. Korelasi Khk dengan IBD pada Subyek

\begin{tabular}{lcc}
$\begin{array}{l}\text { KOLONOSKOPI } \\
(\mathbf{n = 1 6 1 )}\end{array}$ & $\begin{array}{c}\text { Khk } \\
(\mathbf{1 1})\end{array}$ & $\begin{array}{c}\text { Non-Khk } \\
(\mathbf{1 5 0})\end{array}$ \\
\hline IBD (30) & 8 & 22 \\
\hline Non-IBD (131) & 3 & 128 \\
\hline \multicolumn{1}{c}{ Perhitungan } & statistik & pada uji
\end{tabular}

mutlak Fisher dengan memakai $2 \times 2$ Contingency Table, ditemukan $\mathrm{p}=$ 0,0000681 . Hal ini menunjukkan bahwa Kholitis kronik di ekspektasi diterima (tidak ada penolakan) dan berhubungan erat dengan IBD ( $p=0,00007 ; \mathrm{p}<0,05)$. Insidensi Khk pada IBD terhitung dari Subyek terjangkau berarti 8 Subyek mengalami Khk di dalam 30 Subyek IBD, sama dengan $8 / 30$ dari $161 \times 100 \%$, adalah $5,37 \%$ atau $5,4 \%$.

Seluruh subjek penelitian yang dilakukan kolonoskopi, temuan IBD dengan karakter KU (87,5 \%) serta PC (57,1 \%), tidak didukung oleh hasil PA (patologi anatomi).

\section{PEMBAHASAN}

Beberapa parameter klinis penting dapat diungkapkan dari penelitian ini, antara lain adalah sebagai berikut :

\section{Angka kejadian dan karakteristik demografis IBD}

Karakteristik demografis IBD berbeda-beda sesuai dengan faktor geografis. Insidensi penyakit IBD tahun 2016 berdasarkan kolonoskopi $(n=161)$ di RSPAD Gatot Soebroto Puskesad adalah $18,6 \%$. Angka ini lebih tinggi dibandingkan prevalensi IBD tahun 2011 (5 tahun sebelumnya) di RSAPD Gatot Soebroto, yaitu $10,15 \%$ dari 532 pasien yang dilakukan kolonoskopi. ${ }^{12}$

Karakteristik demografi lainnya pada penelitian ini, yakni: 62,4\% (18 orang) dari 30 orang IBD adalah laki-laki, rerata umur adalah 50,6 tahun dengan angka kejadian paling banyak adalah pada usia antara 40 hingga 59 tahun, serta dengan frekuensi 52,8\% PC dan 47,2\% KU.
Penelitian sebelumnya, dengan jumlah sampel yang lebih banyak, di Amerika Utara kejadian IBD mencapai puncak pada usia 15-30 tahun dan 60-80 tahun. ${ }^{2}$ Sedangkan di Asia, penelitian oleh Li Jiang di Cina menunjukkan bahwa kejadian penyakit IBD baik kolitis ulseratif dan penyakit Crohn muncul pada usia 30 hingga 39 tahun. $^{3}$ Hasil serupa juga diperoleh oleh Vahidi dkk pada tahun 2009 di Iran, sebagian besar kasus IBD terjadi pada usia 20 hingga 39 tahun. $^{8}$

Perbandingan antara laki-laki dan perempuan menunjukkan hasil yang serupa dengan penelitian di Amerika Utara, yaitu 1:1 untuk kolitis ulseratif dan 2,2:1 untuk penyakit Crohn. ${ }^{2}$ Begitu pula dengan hasil penelitian di Cina dan Iran yang tidak menunjukkan perbandingan yang terlalu berbeda. ${ }^{2,3}$

\section{Manifestasi klinis IBD}

Manifestasi klinis yang paling sering muncul pada beberapa literatur, adalah diare, pendarahan rektum, dan nyeri perut. Hal ini didukung oleh penelitian $\mathrm{Li}$ Jiang yang memperoleh data bahwa pada pasien kolitis ulseratif dan penyakit Crohn sebagian besar pasien mengeluh diare dan nyeri perut. ${ }^{3}$ Pada penelitian sekarang ini, karakteristik klinis yang paling banyak terjadi pada kasus $\mathrm{KU}$ adalah diare kronik $(13,4 \%)$, nyeri perut $(17,5 \%)$ dan hematoschezia $(6,6 \%)$. Sedangkan pada pasien dengan PC adalah diare kronik $(29,7 \%)$, nyeri perut $(9,9 \%)$ dan hematoschezia $(9,9 \%)$.

Insidensi Kholangitis kronik pada IBD dari semua pasien yang dikolonoskopi selama satu tahun adalah 5,4\%. Angka ini tidak jauh berbeda dari studi kepustakaan sebelumnya.

\section{KESIMPULAN}

Hasil penelitian ini menunjukkan bahwa Insidensi IBD yang terbaru (2017) di RSPAD Gatot Soebroto Puskesad (RSPAD GSP) adalah 18,6\%; dengan karakteristik demografi pasien IBD -nya, sebagian besar pada usia antara 40 hingga 
59 tahun dan lebih banyak pada laki-laki. Manifestasi gejala klinis yang paling sering dikeluhkan adalah nyeri abdomen dan diare kronik. Kholangitis kronik sebagai manifestasi ekstraintestinal IBD ditemukan dengan insidensi sebesar 5,4\%.

Hasil insidensi PSC sebagai manifestasi ekstraintestinal IBD pada penelitian ini dapat memberikan gambaran awal gejala klinis yang mengarahkan para klinisi pada diagnosis IBD dan PSC serta dapat menjadi data awal penelitian selanjutnya.

\section{DAFTAR PUSTAKA}

1. Bonner GF. Current medical therapy for inflammatory bowel disease. South Med J. 1996; 89(6): 556-66.

2. Friedman S. Inflammatory Bowel Disease. Harrison's Principles of Internal Medicine. 17 ed: The McGrawHill Companies. 2008.

3. Jiang L, Xia B, Li J, Ye M, Yan W, Deng $C$, et al. Retrospective survey of 452 patients with inflammatory bowel disease in Wuhan city, central China. Inflamm Bowel Dis. 2006;12(3): 212-7.

4. Willenbucher RF. Inflammatory Bowel Disease. In: Grendel JH, McQuaid KR, Friedman SL. (Eds.) Current Diagnosis and Treatment in Gastroenterology, International Edition a Lange Medical Book. Appleton \& lange. 1996; 7: 95111.

5. Lindor KD. Primary Disease of Bile Ducts. In: Grendel JH, McQuaid KR, Friedman SL. (Eds.) Current Diagnosis and Treatment in Gastroenterology, International Edition a Lange Medical Book. Appleton \& lange. 1996; 51: 6836

6. B.otoman VA, Bonner GF, Botoman DA. Management of inflammatory bowel disease. Am Fam Physician. 1998; 57(1): 57-68, 71-2.
7. Lelosutan SAR. Penyakit Crohn dan Kolitis Ulseratif. In: Rani A, Simadibrata M, Syam AF. (Eds.). Buku Ajar Gastroenterologi, Edisi 1. Interna Publishing, email: pipfkui@yahoo.com; Cet. Pertama: Juli 2011. p. 427-39.

8. Vahedi H, Merat S, Momtahen S, Olfati $\mathrm{G}$, Kazzazi AS, Tabrizian $\mathrm{T}$, et al. Epidemiologic characteristics of 500 patients with inflammatory bowel disease in Iran studied from 2004 through 2007. Arch Iran Med. 2009; 12(5): 454-60.

9. Satsangi J, Silverberg MS, Vermeire S, Colombel J-F. The Montreal Classification of inflammatory bowel disease controversies, consensus and implications. Gut. 2006; 55: 749-53.

10. The British Soceity of Gastroenterology. Guidelines for the initial biopsy diagnosis of suspected chronic idiopathic inflammatory bowel disease. BSG Guidelines in Gastroenterology. 1997.

11. Mayo Clinic Staff. Inflammatory Bowel Disease - Diagnosis and Treatment Option. Available from : http:// www. mayoclinic.com; Update Aug. 2, 2011.

12. Lelosutan SAR, Djojoningrat D, Simadibrata M. (Eds.). Konsensus Nasional Penatalaksanaan Inflammatory Bowel Disease (IBD) di Indonesia. Kelompok Studi IBD Indonesia PB PGI. Jakarta, Interna Publishing. 2011.

13. Lee D, Marks JW. (Eds). Primary Sclerosing Cholangitis. Last Editorial Review:11/21/2007. Available from : http://www.medicinenet.com/primary_s clerosing_ cholangitis/page6.htm.

14. Azwar A, Prihartono J. Metodologi Penelitian Kedokteran dan Kesehatan Masyarakat. Binarupa Aksara. 2003.

15. Penelitian Bidang Kesehatan Keperawatan dan Kebidanan. Penerbit Fitramaya.2005. 